ББК 63.4

$$
\begin{gathered}
\text { Организация конференции и издание материалов проведены } \\
\text { при финансовой поддержке Российского фонда фундаментальных исследований, } \\
\text { проект № 19-09-20008 }
\end{gathered}
$$

Утверждено к печати Ученым советом ИИМК РАН

Редакционная коллегия тома II: А. В. Поляков, Е. С. Ткач (отв. редакторы), М. Т. Кашуба, Л. Б. Кирчо, Е. А. Черлёнок, В. Я. Стёганцева, А. И. Климушина

Рещензенты: д. и. н. Л. Б. Вишняцкий, д. и. н. А. А. Выборнов

Программный комитет конференции: академик РАН, д. и. н., проф. М. Б. Пиотровский (Государственный Эрмитаж, почетный председатель); д. и. н. В. А. Лапшин (ИИМК РАН, председатель); д. и. н. А. В. Головнёв (МАЭ РАН, сопредседатель); д. и. н. В. А. Дергачёв (Высшая антропологическая школа, Молдова, сопредседатель); д. и. н. И. Ф. Попова (ИВР РАН, сопредседатель); академик АН Республики Узбекистан, д. и. н., проф. Э. В. Ртвеладзе (сопредседатель); к. и. н. А. В. Поляков (ИИМК РАН, зам. председателя); к. и. н. В. А. Алёкшин (ИИМК РАН, зам. председателя); д. и. н. Ю. Е. Берёзкин (МАЭ РАН); Dr., Prof. Н. Бороффка

(Германский археологический институт, Германия); В. С. Бочкарёв (ИИМК РАН);

Dr. Э. Кайзер (Свободный университет Берлина, Германия); к. и. н. М. Т. Кашуба (ИИМК РАН); д. и. н. Л. Б. Кирчо (ИИМК РАН); к. и. н. А. В. Кияшко (Южный федеральный университет); к. и. н. П. Ф. Кузнецов (СГСПУ); к. и. н. Н. М. Малов (СНИГУ); к. и. н. В. П. Никоноров (ИИМК РАН); Ю. Ю. Пиотровский (Государственный Эрмитаж); д. и. н., проф. Д. Г. Савинов (Институт истории СПбГУ); к. и. н. В. Н. Седых (Институт истории СПбГУ); к. и. н. Н. Н. Скакун (ИИМК РАН); к. и. н. Н. Ф. Соловьёва (ИИМК РАН); к. и. н. А. И. Торгоев (Государственный Эрмитаж); к. и. н. Е. А. Черлёнок (Институт истории СПбГУ)

Организационный комитет конференции: к. и. н. А. В. Поляков (ИИМК РАН, председатель); к. и. н. В. А. Алёкшин (ИИМК РАН, зам. председателя); В. С. Бочкарёв (ИИМК РАН); к. и. н. М. Т. Кашуба (ИИМК РАН); д. и. н. Л. Б. Кирчо (ИИМК РАН);

А. И. Климушина (ИИМК РАН, отв. секретарь); к. и. н. В. П. Никоноров (ИИМК РАН); Ю. Ю. Пиотровский (Государственный Эрмитаж); В. Я. Стеганцева (ИИМК РАН); В. В. Терёхина (ИИМК РАН, МАЭ РАН, отв. секретарь); к. и. н. Е. С. Ткач (ИИМК РАН); И. Ж. Тутаева (Государственный Эрмитаж); к. и. н. Е. А. Черлёнок (Институт истории СПбГУ)

Древности Восточной Европы, Центральной Азии и Южной Сибири в контексте связей и взаимодействий в евразийском культурном пространстве (новые данные и концепции): Материалы Международной конференции, 18-22 ноября 2019 г., Санкт-Петербург. Т. ІІ. Связи, контакты и взаимодействия древних культур Северной Евразии и цивилизаций Востока в эпоху палеометалла (IV-I тыс. до н. э.). К 80-летию со дня рождения выдающегося археолога В. С. Бочкарёва. - СПб.: ИИМК РАН, Невская Типография, 2019. - 287 с.

ISBN 978-5-907053-35-9

DOI 10.31600/978-5-907053-35-9 
Манзура И. В. 2004. Северное Причерноморье в энеолите и в начале бронзового века: ступени колонизации // Stratum plus. № 2. С. 63-85.

Мовша Т. Г. 1961. О связях племен трипольской культуры со степными племенами медного века // СА. № 2. С. 186-199.

Kalinina K., Starkowa E., Urjupow S. 2018. Nauki przyrodnicze w badaniu ceramiki kultury trypolskiej: problemy i perspektywy // Badania archeologiczne w Polsce środkowowschodniej, zachodniej Białorusi i Ukrainie w roku 2017. Lublin. S. 12.

Palaguta I. 2007. Tripolye Culture during the Beginning of the Middle Period (BI): The relative chronology and local grouping of sites. Oxford (BAR. IS. 1666).

Schmidt H. 1932. Cucuteni in der Oberen Moldau, Rumänien. Berlin; Leipzig.

Starkowa E. 2017. Elementy stepowe w kulturze Cucuteni-Trypole: przyczynek do dyskusji // Badania archeologiczne w Polsce środkowowschodniej, zachodniej Białorusi i Ukrainie w roku 2017. Lublin. S. 15.

\title{
POTTERY WITH ADMIXTURES OF POUNDED SHELLS IN TRIPOLYE CULTURE: THE HISTORY OF ONE HYPOTHESIS
}

Elena G. Starkova, Sergey O. Uryupov

The State Hermitage Museum, St. Petersburg, Russia

Keywords: Tripolye culture, GC-MS method, ceramics with admixtures of pounded shells, Eneolithic steppe cultures.

Ceramics with admixtures of shell in the clay appears in the Tripolye complexes in the $5^{\text {th }}-4^{\text {th }}$ mill. BC. It spreads across the greater part of the culture's area and is considered as one of the most important signs of contacts between the Tripolye population and Eneolithic steppe cultures. This feature becomes a functional category of the Tripolye's "cooking ware". Ceramics with shell admixture needs a lower firing temperature in comparison with the conventional Tripolye "cooking ware". It is possible that is had been fired not in kilns but in covered pits or in domestic fireplaces without a regulated oxygen flow rate. A new idea has started up as to the usage of "cooking ware" with shell admixtures in the clay for special purpose related to a specific type of foodstuff. Alkaline condition due to the presence of calcium carbonate possibly allowed keeping milk longer preserving it from curdling. Researches by the GC-MS method demonstrated a difference in composition of organic residues obtained from shell-containing and ordinary Tripolye cookware.

\section{КЕРАМИКА В ЭТНОКУЛЬТУРНЫХ РЕКОНСТРУКЦИЯХ: ИЛЛЮЗИИ СХОДСТВ И РАЗЛИЧИЙ И ЗАКОНОМЕРНОСТИ ПРОИЗВОДСТВА}

\author{
И. В. Палагута \\ Санкт-Петербургская государственная художественно-промышленная академия \\ им. А. Л. Штиглии, Санкт-Петербург, Россия
}

DOI: 10.31600/978-5-907053-35-9-138-140

Ключевые слова: археологическая керамика, исследование технологий, керамический комплекс, системный подход, сравнительный анализ.

При построении этнокультурных реконструкций, выявлении связей между культурами и между группами однокультурных памятников керамика, вследствие многочисленности находок и разнообразия признаков, является одним из важнейших материалов. Однако при сравнительном анализе важно учитывать весь набор свойств посуды, а не одну какую-либо характеристику, например, морфологию сосудов или состав глиняного теста. 
Существует масса примеров, когда использование одного из признаков приводит к построению эфемерных реконструкций и синхронизаций. Приведу некоторые из них, связанные с материалом, относящимся к энеолиту - бронзовому веку.

Типичным примером является проведение параллелей в формах шнуровой керамики и керамики карасукской культуры, использовавшееся Л. С. Клейном для аргументации гипотезы о миграции тохаров (Клейн 2000). Однако сходство формы между сосудами этих культур обусловлено не генетической связью, а использованием в обоих случаях техники выбивки. Иначе «тохарской» легко может стать керамика Меланезии (Кожин, Иванова 1974) или ряда областей Африки.

Кажущееся сходство отдельных элементов позволило Н. Б. Бурдо выстроить синхронизмы между культурами Триполье и Тисаполгар (Бурдо 2007), но «влияния» оказываются исключительно субъективным предположением автора, сопоставлявшего рисунки из публикаций (см.: Палагута, Старкова 2018). Продолжением этой темы является статья о керамике с примесью дробленой раковины в трипольско-кукутенских комплексах: манипулируя отдельными признаками, автор критикует предложенные ранее объяснения, однако не предлагает реальную реконструкцию событий. В итоге «типологическая однородность керамики типа Кукутень С на просторах от Карпат до Днепра на протяжении сотен лет» объясняться «только общностью сакральной традиции» (Бурдо 2016: 28).

Между тем исследование конкретных материалов показывает, что на первом этапе своего появления на трипольско-кукутенских поселениях данная разновидность керамики (в отличие от местной) не только имеет особую примесь в тесте, но и сформована иным способом (использование выбивки), иначе орнаментирована, обожжена не в окислительной, а в восстановительной среде. Соответственно, при изготовлении такой посуды мастер демонстрировал иное, чем в Триполье, восприятие формовочного материала, владение иными техниками работы с ним и обжигал их отдельно (Палагута 2016: 201). Сопоставление ее с посудой энеолита степи показывает отнюдь не «приблизительное сходство» (Бурдо 2016: 17), а аналогичную технологическую цепочку: поэтому можно предположить, что эти сосуды демонстрируют «инкорпорацию носителей “степной” традиции в среду раннеземледельческих общин» (Палагута 1998: 12; 2016: 202). Тезис о «степных женах», почему-то со ссылкой на мою статью 1998 г. (см.: Палагута 2008), присутствует в целом ряде работ (Котова 2006: 129; Ковалёва 2012: 9), но указанный процесс мог иметь различные формы. В дальнейшем эта посуда адаптируется в трипольской среде, выступая в виде особой функциональной категории (Старкова 2008), а отнюдь не «сакральной традиции».

Таким образом, «изучение керамики как продукции определенных исполнителей, изготовлявших керамику по единым или же по различным правилам» (Кожин 1989: 56), предусматривает ее рассмотрение в рамках функционально-производственного комплекса, отраженного в археологических комплексах поселений, как системы, где взаимосвязаны все стадии технологического процесса: подготовка сырья, методы лепки и формовки, способы орнаментации, среда и температура обжига, подготовка к употреблению.

Это не отрицает разработку массивов керамического материала на уровне отдельных признаков или технологических стадий. Так, в условиях фрагментированного материала дает результаты измерение твердости по шкале Мооса (Козинцев 2017). То же можно сказать и об анализе состава керамических масс в пределах достаточно однородной культурной зоны, например, в рамках культуры линейно-ленточной керамики (Kadrow, Rauba-Bukowska 2017).

\section{Литература}

Бурдо Н. Б. 2007. Спільні керамічні традиції культур Карпато-дунайського регіону доби раннього енеоліту // Bakalarska L. (red.), Wspólnota dziedzictwa archeologicznego ziem Ukrainy i Polski. Warszawá. P. 270-288. 
Бурдо Н. Б. 2016. Керамика «типа Кукутень С» в керамических ансамблях культурного комплекса Кукутень-Триполье (Постановка проблемы и краткая историография) // Tyragetia S. N. Vol. 10 (25), nr. 1. C. 7-38.

Клейн Л. С. 2000. Миграция тохаров в свете археологии // Stratum plus. № 2. С. 178-187.

Ковалёва И. Ф. 2012. Скелянская культура. Историография проблемы // Ковальова І. Ф. (відп. ред.). Проблеми археології Подніпров’я: Міжвуз. зб. наук. пр. Дніпропетровськ. С. 3-11.

Кожин П. М., Иванова Л. А. 1974. Океанийская керамика в собраниях МАЭ // Культура народов Австралии и Океании. СПб. С. 112-126 (Сборник МАЭ. Вып. 30).

Кожин П. М. 1989. Значение керамики в изучении древних этнокультурных процессов // Бобринский А. А. (отв. ред.). Керамика как исторический источник. Новосибирск. С. 54-70.

Козинцев А. Г. 2017. Опыт обобщенной оценки культурной динамики на многослойных памятниках (по материалам энеолитических крепостей Закубанья) // АЭАЕ. № 1 (45). С. 62-75.

Котова Н. С. 2006. Ранний энеолит степного Поднепровья и Приазовья. Луганск.

Палагута И. В. 1998. К проблеме связей Триполья-Кукутени с культурами энеолита степной зоны Северного Причерноморья // РА. № 1. С. 5-14.

Палагута И. В. 2016. Трипольская культура в начале развитого периода (BI): Относительная хронология и локальные варианты памятников. Киев.

Палагута И. В., Старкова Е. Г. 2018. Проблемы относительной хронологии Триполья-Кукутень и окружающих культур Балкано-Карпатского региона: радиокарбонные даты и археологические материалы // Кашуба М. Т., Кайзер Э. (отв. ред.). Принципы и методы датирования в археологии (неолит - средние века). СПб. С. 97-123.

Старкова Е. Г. 2008. Керамика типа Кукутени С на трипольских памятниках периода BII-CI // PA. № 3. C. 16-25.

Kadrow S., Rauba-Bukowska A. 2017. The selection of ceramic raw material: convenience or a technological idea? A case study of the Danubian cultures north of the Carpathians. In: Archeologické rozhledy. R. 69-2. P. 261-280.

\section{CERAMICS IN ETHNOCULTURAL RECONSTRUCTIONS: ILLUSIONS OF SIMILARITIES AND DIFFERENCES CONCERNED WITH THE PRINCIPLES OF PRODUCTION}

\section{Il'ya V. Palaguta}

Saint Petersburg Stieglitz State Academy of Art and Design, St. Petersburg, Russia

Keywords: archaeological ceramics, pottery-making technology, ceramic assemblage, systematic approach, comparative analysis.

In comparative analysis of ceramics, it is important to consider the whole set of properties of the pottery, and not just one of its characteristics. The use of a single attribute can lead to ephemeral reconstructions and synchronizations. The present report is dealing with examples of constructing of such schemes relative to the Eneolithic and Bronze Age. A study of ceramics "as products of particular pottery-makers who produced pottery according to a single or differing techniques" (Кожин 1989) provides its consideration within a functional and production complex reflected in archaeological assemblages as a system of interrelated stages of the technological process: preparation of raw materials, molding and forming techniques, methods and style of ornamentation, the character of the environment and firing temperature, and preparation for usage. This fact in no way negates an examination of the arrays of ceramic material at the level of their individual attributes or technological stages in cases of strong fragmentation of the materials or when studying pottery within a homogeneous cultural area. 